\title{
A meta-analysis of the influence of the external conditions on the biosensor receptor layer component stability
}

\author{
Aleksandra Klos-Witkowska ${ }^{\square}$ and Vasyl Martsenyuk \\ Department of Computer Science and Automatics, University of Bielsko-Biala, 43-309 Bielsko-Biala, Poland
}

\begin{abstract}
The manuscript presented here contains meta-analysis of the influence of the external conditions on the biosensor receptor layer component stability. The novelty of this paper is due to compilation and comparison of studies, based on proposed collective analyses. The presented meta-analysis allows to increase the precision and accuracy of the results by combining and co-analyzing data from five smaller experiments. To understand the significance of presented meta-analysis, the most important conclusions and observations resulting from the conducted five types of research [F1] to [F5] are given. The conducted meta-analysis showed the magnitude of stability differences caused by different external factors. An approach of numerical interpretation of the qualitative stability changes has been offered. The conducted metaanalysis showed that the tested factors influence the stability of the BSA in different ways
\end{abstract}

Keywords: biosensor, stability, BSA

Received: 12 January, 2021; revised: 03 March, 2021; accepted: 10 March, 2021; available on-line: 27 April, 2021

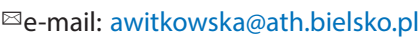

Abbreviations: BSA, Bovine Serum Albumin; NAA, N-Acety-L-aspartic acid

\section{INTRODUCTION}

Among the parameters influencing biosensor operation, the issue of stability can be distinguished. This problem is important, as the stability of parameters of the device translates into a feasible operational lifetime. Stability and methods of qualitative analysis are often addressed by research groups (Sonawane et al., 2017; Martsenyuk et al., 2016; Penjan et al., 2017; Grabowska et al., 2014; Mosinska et al., 2013). This problem is still open and it will remain open without a doubt in the future. The "biosensor stability" keyword entered in the Web of Science database returns 818 articles for 2019 only, which confirms that the issue is still open. In the biosensor matrix, the active biological material is immobilized. There are several popular methods of immobilization in use. They include entrapment, covalent bonding, adsorption, encapsulation and cross-linking (Kucherenko et al., 2019; Sirisha et al., 2016)

The performed study is related to the cross-linking component of the biosensor receptor layer. This component is BSA (Bovine Serum Albumin). Among the examined methods of immobilization, cross-linking with BSA is superior to other methods in terms of sensitivity, detection threshold, reaction time, as well as operational and thermal stability (Sarika et al., 2015).
The biosensor receptor layer cross-linking component used in the examinations is often used when designing new tests (Żyracka et al., 2005) . It also defines the standard of proteins on glass bed coated with a surfactant, immersed in the indium tin oxide (ITO) electrodes (Lin et al., 2016). Due to the fact that the tested substance is commonly used in pharmacokinetics and pharmacodynamics of new medicaments, its conformational changes under the influence of external factors have been examined before (Zhou at al., 2019; Neuhoff et al., 2006; Torres et al., 2013). However, there is no any information about the type of research we performed, i.e. the influence of the above-mentioned external factors on the cross-linking component of the biosensor receptor layers. The research in this respect was aimed to determine the stability of the biosensor receptor layer crosslinking component in specific time intervals. The aim of the study is to conduct a meta-analysis of the influence of external conditions on biosensor receptor layer stability. The study will allow to increase the precision and accuracy of assessment of the influence of the different factors on the stability of the biosensor receptor layer component. The planned compilation will allow to distinguish factors that improve stability and the destabilizing factors. This study complements the knowledge on the stability of the biosensor receptor layer component.

A diagram of performed tests is illustrated by Fig. 1.

The novelty of this paper is centralizing and compilation of studies based on proposed collective analyses, which are the resultant of source articles. The presented meta-analysis allows to increase the precision and accuracy of the results by combining and co-analyzing data from several smaller experiments. The results come from those five small experiments that were published before separately. In the presented manuscript the results are put together and compared with the use of new metanalysis. The novelty of the paper follows from the comparison of the external factors concerning operational and self-stability. The results demonstrated in this manuscript can be used in the design of biosensors. They help to determine the conditions for storage of that type of devices to prolong their stability. Description of the results leading to conclusions about the stability of the receptor layer crosslinking component used in biosensor matrices. Stability of this component is a very important element, as it forms a kind of a binding element (e.g. for enzymes in the enzyme biosensors) and a change in its conformation may lead to destabilization of the receptor layer structure.

\section{MATERIALS AND METHODS}

Bovine Serum Albumin (BSA) as a solid (crystallized and lyophilized powder (purity at least 99\%), essential- 


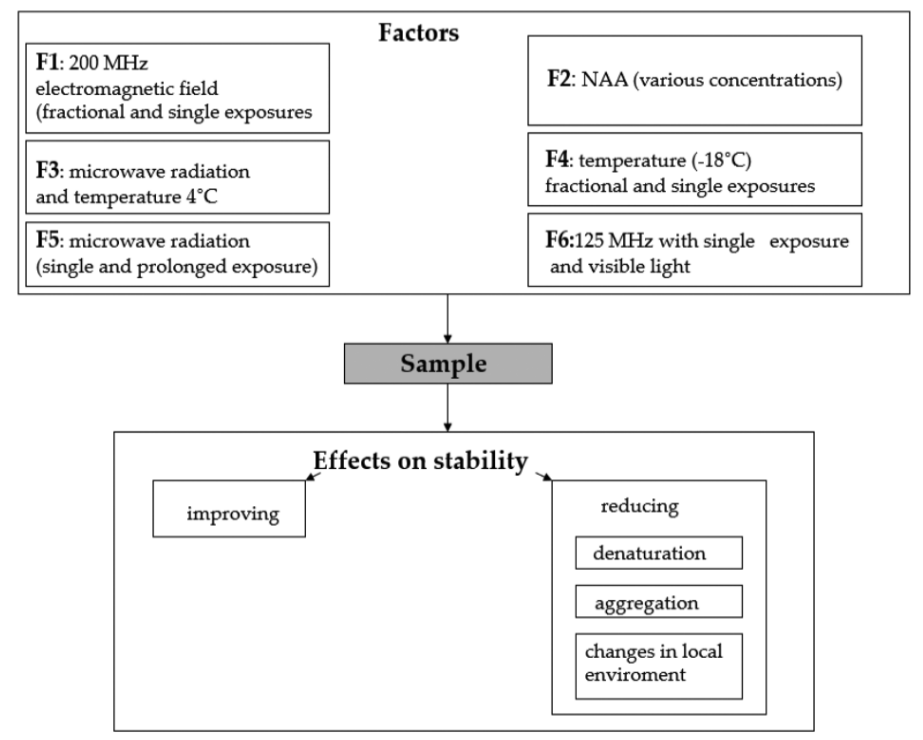

Figure 1. Diagram of applied external factors on the receptor layer component.

ly globulin free BSA (lot: SLBK3063V)) was obtained from Sigma-Aldrich. Bovine Serum Albumin aqueous solution $(2 \mathrm{mg} / \mathrm{ml})$ has been investigated. The tests were performed on aqueous solutions, on the basis of scientific reports (Michnik et al., 2005) that such a solution provides a better understanding of the physicochemical properties of the tested substances. To determine the characteristics of the applied electromagnetic field to BSA aqueous solution, a special experimental setup was constructed. It contains a source of electromagnetic field (wave generator), BSA solutions, EMC-Scanner model RSE321, a spectrum analyzer with near field probe and a standard computer. Electromagnetic field scans were collected at $200 \mathrm{MHz}$. Scans were made in the Y $\mathrm{Z}$ plane before the sample (area $2 \mathrm{~cm} \times 2 \mathrm{~cm}$ ) and behind the sample $(2 \mathrm{~cm} \times 2 \mathrm{~cm})$. The absorption spectra in the range of $250-300 \mathrm{~nm}$ were examined with the use of double-beam UV/Vis spectrophotometers (Halo DB20R) Dynamica.

The track changes in the absorption peak of a protein solution are resulting from the occurrence in the protein of the aromatic residues, such as tryptophan (Trp), tyrosine (Tyr) and Phenyloalanine (Phe) (Hongliang et al., 2013).

In [F1] experiment $200 \times 1$ is a description of the sample that was exposed to the $200 \mathrm{MHz}$ only once in 60 min on the first day of the experiment; $200 \times 2$ concern sample exposed to $200 \mathrm{MHz}$ two times $(60 \mathrm{~min}$ in the first day of the experiment and $60 \mathrm{~min}$ in the second day of the experiment); $200 \times 3$ means exposition to 200 $\mathrm{MHz}$ thrice: $60 \mathrm{~min}$ in the first day, $60 \mathrm{~min}$ in the second day, $60 \mathrm{~min}$ in the third day.

For [F2] experiment, brain metabolite NAA (N-Acetyl-L-aspartic acid) (lot: BCBR3519) was obtained from Sigma-Aldrich. An aqueous solution of the BSA and BSA-NAA mixture was investigated.

The study has been performed for two NAA concentrations: for NAA $1 \mathrm{mg} / \mathrm{ml}$ (1 NAA) and for NAA $3 \mathrm{mg} /$ $\mathrm{ml}$ (3NAA). In additional, the mixture has been tracked at $4^{\circ} \mathrm{C}$ and $22^{\circ} \mathrm{C}$.

$1 \mathrm{NAA}$ means a solution of $2 \mathrm{mg} / \mathrm{ml} \mathrm{BSA}$ with $1 \mathrm{mg} / \mathrm{ml} \mathrm{NAA}$ stored at $22^{\circ} \mathrm{C} ; 1 \mathrm{NAA} 4{ }^{\circ} \mathrm{C}$ means a solution of $2 \mathrm{mg} / \mathrm{ml} \mathrm{BSA}$ with $1 \mathrm{mg} / \mathrm{ml} \mathrm{NAA}$ stored at $4^{\circ} \mathrm{C}$; $3 \mathrm{NAA}$ means a solution of $2 \mathrm{mg} / \mathrm{ml}$ BSA with 3 $\mathrm{mg} / \mathrm{ml} \mathrm{NAA}$ stored at $22^{\circ} \mathrm{C} ; 3 \mathrm{NAA} 4^{\circ} \mathrm{C}$ means a solution of $2 \mathrm{mg} / \mathrm{ml} \mathrm{BSA}$ with $3 \mathrm{mg} / \mathrm{ml} \mathrm{NAA}$ stored at $4^{\circ} \mathrm{C}$

[F3] stands for a study considering the influence of microwave radiation and lowered temperature $\left(4^{\circ} \mathrm{C}\right)$.

The solution was divided into groups. One of them was stored at a reduced temperature $\left(4^{\circ} \mathrm{C}\right)$, and the next group was exposed to microwave radiation (10 seconds, the power of $750 \mathrm{~W})$, then after $30 \mathrm{~min}$ it was also inserted in the refrigerator $\left(4^{\circ} \mathrm{C}\right.$ ) (microwave $10 \mathrm{~s}$ and $\left.4^{\circ} \mathrm{C}\right)$.

[F4] describes changes occurring in time under the influence of an external factor, which was the reduced temperature $\left(-18^{\circ} \mathrm{C}\right)$. A single exposure lasted $60 \mathrm{~min}$ utes at $\left(-18^{\circ} \mathrm{C}\right)(\times 1)$ for the first group.

The second group of the sample has been treated with an external agent $\left(-18^{\circ} \mathrm{C}\right)$ twice $(\times 2)$, on the first and second day of the experiment.

The third group of the sample was subjected to three times of exposure $\left(-18^{\circ} \mathrm{C}\right)$. On the first, second and third day of the experiment $(\times 3)$ [F5] concerns microwave radiation applied in fractional and single doses. In the case of single doses, the exposure to microwaves lasted: $10 \mathrm{~s}, 15 \mathrm{~s}$. No change in temperature of the radiated systems was observed due to the short time of the applied agent.

For fractional doses, radiation was administered in fractions: double $(5 s \times 2)$, the sample was exposed to microwaves twice for $5 \mathrm{~s}$ each, and a triple $(5 \mathrm{~s} \times 3)$ sample was exposed to microwaves three times for $5 \mathrm{~s}$ each; the time intervals for multiple fractional doses were 3 hours, the radiation power was $160 \mathrm{~W}$. The short radiation time did not cause thermal effects.

\section{RESULTS AND DISCUSSION}

\section{The most important conclusions and observations resulting from the conducted five types of research [F1] to [F5] one by one}

To understand the significance of the presented metaanalysis, the most important conclusions and observations resulting from the conducted five types of research [F1] to [F5] are given. 
[F1]: $200 \mathrm{MHz}$ electromagnetic field (fractional and single exposures)

Based on the completed experiments and required analyses (Klos-Witkowska, 2018) it has been shown that:

- there is a cumulative effect of the $200 \mathrm{MHz}$ electromagnetic field impact on the receptor layer cross-linking component,

- exposure to the $200 \mathrm{MHz}$ electromagnetic fields improves the stability of the receptor layer cross-linking component in biosensors,

- multiple exposures of the receptor layer cross-linking component in biosensors to the $200 \mathrm{MHz}$ electromagnetic field improves the component stability.

A very important effect of these tests is a statement that exposure to electromagnetic field (200 MHz) slows down changes occurring in the cross-linking component of the biosensor receptor layer as time passes. This effect is more pronounced for multiple exposures, as compared to single exposure (dosed fractionally).

\section{[F2]: NAA (various concentrations)and temperature $4^{\circ} \mathrm{C}$}

Tests of stability over time and under variable acidity of the environment and reduced temperature (KlosWitkowska \& Martsenyuk, 2020; Klos-Witkowska et al., 2018) showed the following effects:

- lower stability of biosensor receptor layer components over time,

- changed acidity of the environment by addition of NAA,

- improved stability of BSA-NAA complexes at reduced temperature,

- improved stability of tested biosensor receptor layer cross-linking components as NAA concentration rises and the temperature is reduced.

Completion of the test plan provides evidence that adding NAA to the tested cross-linking

component of the biosensor receptor layer improves its stability. Storage at the temperature of $4^{\circ} \mathrm{C}$ above zero improves the stability of the cross-linking component of biosensor receptor layers.

[F3]: microwave radiation and lowered temperature $\left(4^{\circ} \mathrm{C}\right)$

Tests presented in publication (Klos-Witkowska et al., 2016) provided evidence for:

- improvement of the stability of the biosensor receptor layer cross-linking component under temperature reduced to $4^{\circ} \mathrm{C}$, however, with a concurrent increase in the rate of conformational changes (ageing) under microwave radiation $(2.4 \mathrm{GHz}, 160 \mathrm{~W})$,

- regardless of the exposure of the biosensor receptor layer cross-linking component to the applied factors (radiation, temperature), progressing conformational changes in time are observed for them.

[F4]: temperature $\left(-18^{\circ} \mathrm{C}\right)$ fractional and single exposures

The completed tests provided evidence for:

- reduction of the stability of the cross-linking component of biosensor receptor layers

- caused by the reduction of temperature to the level of $-18^{\circ} \mathrm{C}$

- more evident differences between the sample exposed to the factor and control sample, increasing over time. These tests showed that storage of biosensors at such low temperatures should be avoided, as that large reduction in temperature degrades the stability of the cross-linking component of biosensor receptor layers. This means that biosensors should not be stored in refrigerators. On the other hand, storage in coolers is recommended. Results of these tests were presented in publication (Klos-Witkowska, 2017).

\section{[F5]: microwave radiation (single and prolonged exposure)}

The results of completed experiments and analyses were presented in publication (Klos-Witkowska, 2017), in which we provided evidence for:

- the influence of microwave radiation on the stability of the cross-linking component of biosensor receptor layers showing accelerated denaturation processes,

- the impact of radiation in both fractional and single exposure modes,

- higher stability of the samples exposed to fractional radiation,

- more evident differences between the sample exposed to the factor and control sample over time.

To recapitulate, the obtained results of tests covering the impact of selected factors on the stability of the biosensor receptor layer indicate:

- favourable influence of the radiofrequency field ranges of $200 \mathrm{MHz}$ on the stability of the cross-linking component of biosensor receptor layers,

- favourable influence of multiple exposures to the radiofrequency field ranges of $200 \mathrm{MHz}$ on the stability of the cross-linking component of biosensor receptor layers,

- unfavourable influence of light on the stability of the cross-linking component of biosensor receptor layers,

- favourable influence of the increase in NAA concentration and reduction in temperature to $+4^{\circ} \mathrm{C}$ on the stability of the cross-linking component of the biosensor receptor layers,

- unfavourable influence of the microwave radiation (single exposure and fractional exposure to radiation) on the stability of the cross-linking component of biosensor receptor layers,

- unfavourable influence of temperature of $-18^{\circ} \mathrm{C}$ on the stability of the cross-linking component of biosensor receptor layers,

- more evident differences between the sample exposed to the selected factors and control sample over time.

\section{Meta-analysis of [ F1] to[ F5] experiments. Compilation and comparison of all studies}

To compare the influence of F1 to F5 factors on the stability of the receptor layer cross-linking component in biosensors, a meta-analysis has been conducted.

In the first step, we have compiled all of the experiments carried out. The results are listed below in $\mathrm{Ta}$ ble 1 .

A new type of analysis was carried out to compare the impact of external factors affecting the stability of the receptor layer cross-linking component in biosensors. We have offered an approach of numerical interpretation of the qualitative changes of stability.

Special meta-analysis has been performed to determine which of the applied factors affected the most the stability of the receptor layer cross-linking component in biosensors. For this purpose relative percentage differences were calculated based on a formula

$\mathrm{K}=\left(\mathrm{A}_{1} / \mathrm{A}_{0}\right) \cdot 100$

where: $A_{1}-$ absorption under the influence of the factor in the following days of the study; $A_{0}-$ absorption of control samples

Then, based on the formula

$\mathrm{M}=100-\mathrm{K}$ 
Table 1. Comparison of conducted experiments [F1] to [F5] and stability changes examined on appropriate days of the experiments

\begin{tabular}{|c|c|c|c|c|c|c|c|c|c|c|c|c|c|c|c|c|}
\hline \multirow[t]{3}{*}{ Days } & \multicolumn{4}{|c|}{$\mathrm{F} 1$} & \multicolumn{3}{|c|}{$\mathrm{F} 2$} & \multicolumn{2}{|r|}{ F3 } & \multicolumn{3}{|c|}{$\mathrm{F} 4$} & \multicolumn{4}{|c|}{ F5 } \\
\hline & \multicolumn{4}{|c|}{$200 \mathrm{MHz}$} & \multicolumn{2}{|c|}{$4^{\circ} \mathrm{C}$} & \multirow[b]{2}{*}{$\begin{array}{l}3 \text { NAA } \\
4^{\circ} \mathrm{C}\end{array}$} & \multirow[b]{2}{*}{$4^{\circ} \mathrm{C}$} & \multirow[b]{2}{*}{$\begin{array}{c}\text { mirowave } \\
10 \mathrm{~s} \text { and } 4^{\circ} \mathrm{C}\end{array}$} & \multicolumn{3}{|c|}{$-18^{\circ} \mathrm{C}$} & \multirow[b]{2}{*}{$x 2$} & \multicolumn{3}{|c|}{ microwave } \\
\hline & $x 1$ & $x 2$ & $x 3$ & $1 \mathrm{NAA}$ & $\begin{array}{l}1 \mathrm{NAA} \\
4^{\circ} \mathrm{C}\end{array}$ & 3 NAA & & & & $x 1$ & $x 2$ & $x 3$ & & $x 3$ & $10 \mathrm{~s}$ & $15 \mathrm{~s}$ \\
\hline 1 & + & + & + & + & + & + & + & + & + & + & + & + & + & + & + & + \\
\hline 2 & + & + & + & + & + & + & + & & & + & + & + & & & & \\
\hline 3 & + & + & + & + & + & + & + & & & + & + & + & & & & \\
\hline 4 & & & & + & + & + & + & & & + & + & + & + & + & + & + \\
\hline 5 & & & & + & + & + & + & & & + & + & + & & & & \\
\hline 6 & & & & + & + & + & + & & & + & + & + & + & + & + & + \\
\hline 7 & & & & + & + & + & + & & & & & & & & & \\
\hline 8 & + & + & + & + & + & + & + & + & + & & & & + & + & + & + \\
\hline 9 & & & & + & + & + & + & & & & & & & & & \\
\hline 10 & + & + & + & + & + & + & + & & & & & & & & & \\
\hline 11 & & & & + & + & + & + & & & & & & + & + & + & + \\
\hline 12 & & & & + & + & + & + & & & & & & & & & \\
\hline 13 & & & & & & & & & & & & & & & & \\
\hline 14 & & & & & & & & & & & & & & & & \\
\hline 15 & & & & & & & & + & + & & & & & & & \\
\hline 16 & + & + & + & & & & & & & & & & & & & \\
\hline 17 & & & & & & & & & & & & & & & & \\
\hline 18 & & & & & & & & & & & & & & & & \\
\hline 19 & & & & & & & & & & & & & & & & \\
\hline 20 & & & & & & & & & & & & & & & & \\
\hline 21 & & & & & & & & & & & & & & & & \\
\hline 22 & & & & & & & & + & + & & & & & & & \\
\hline 23 & & & & & & & & & & & & & & & & \\
\hline 24 & & & & & & & & & & & & & & & & \\
\hline 25 & & & & & & & & & & & & & & & & \\
\hline 26 & & & & & & & & & & & & & & & & \\
\hline 27 & & & & & & & & & & & & & & & & \\
\hline 28 & & & & & & & & & & & & & & & & \\
\hline 29 & & & & & & & & + & + & & & & & & & \\
\hline
\end{tabular}

The percentages of changes in individual days were calculated $\mathrm{M}_{1}, \mathrm{M}_{2}, \mathrm{M}_{3, \ldots .} \mathrm{M}_{\mathrm{y}}$.

Based on them, adding up their values, relative ratios were obtained $\left(M_{D x}\right)$, where $x=1,2 \ldots$.

$\mathrm{M}_{1}+\mathrm{M}_{2}=\mathrm{M}_{\mathrm{D} 1}$

$\mathrm{M}_{2}+\mathrm{M}_{3}=\mathrm{M}_{\mathrm{D} 2}$,

$\mathrm{M}_{3}+\mathrm{M}_{4}=\mathrm{M}_{\mathrm{D} 3}$.

Based on the coefficients $\mathrm{M}_{\mathrm{Dx}}$, a graph illustrating the change in $\mathrm{M}_{\mathrm{Dx}}$ value in subsequent days of the experiment was made, and then fitting of functions into a logarithmic trend has been performed.

$\mathrm{M}_{\mathrm{Dx}}$ matching with a description of logarithmic functions in the form $y=a \operatorname{Ln}(\mathrm{x}) \pm \mathrm{b}$ for selected coefficients is presented in Fig. 2.
The chart shows the rising character for $y 1, y 2, y 3$ and sloping character for $\mathrm{y} 4, \mathrm{y} 5, \mathrm{y} 6$.

It was interpreted that the parameter "a" in the description of the logarithmic function $y=a \operatorname{Ln}(x) \pm b$ is a parameter demonstrating the nature of changes in stability.

When an increase in stability is observed, the parameter "a" takes positive values, whereas when the decrease in stability is noticeable, then this parameter takes a negative value. And so for the y1 coefficients illustrate the F1 experiment $(200 \mathrm{MHz} \times 3)$, y2 illustrates the F1 experiment $(200 \mathrm{MHz} \times 2)$ and y3 illustrates the $\mathrm{F} 3$ experiment $\left(4^{\circ} \mathrm{C}\right)$ the factors $200 \mathrm{MHz}$ and $4^{\circ} \mathrm{C}$ are improving stability of receptor layer component in biosensors, whereas $\mathrm{y} 4, \mathrm{y} 5$, y 6 coefficients illustrating the $\mathrm{F} 4\left(-18^{\circ} \mathrm{C} \times 3\right), \mathrm{F} 4\left(-18^{\circ} \mathrm{C} \times 2\right), \mathrm{F} 4\left(-18^{\circ} \mathrm{C} \times 1\right)$ reduce the 


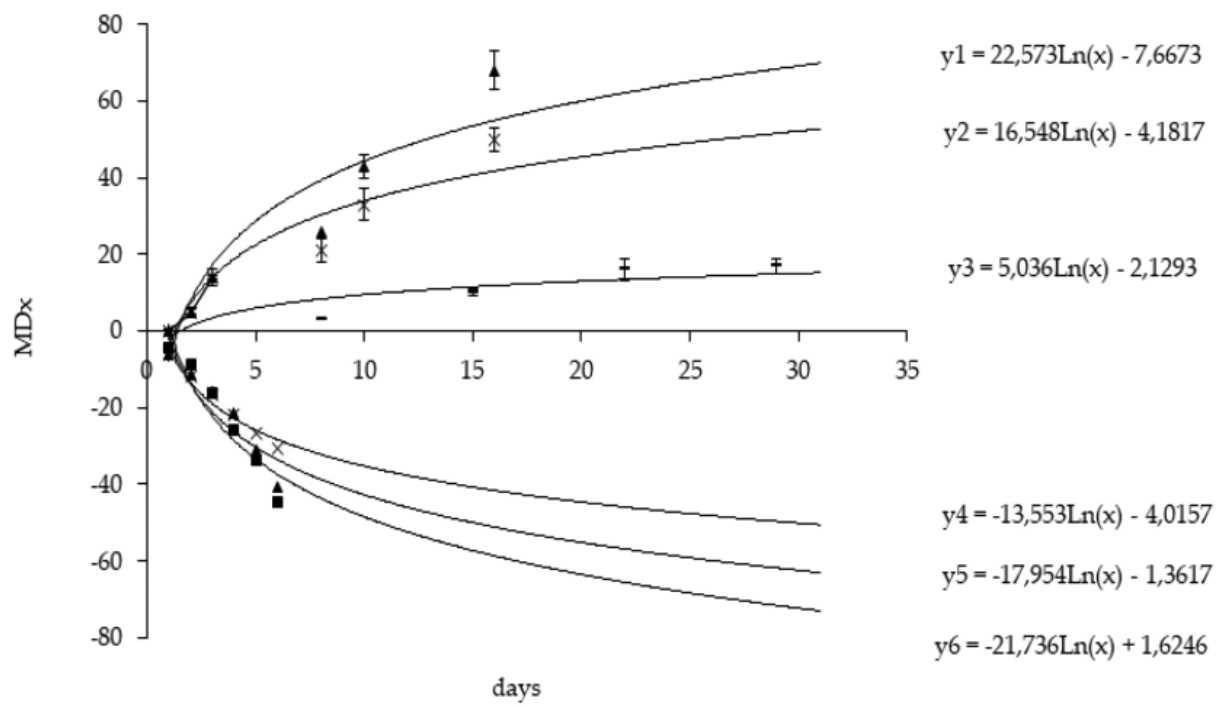

Figure 2. $M_{D x}$ matching with the description of logarithmic functions for selected coefficients $y 1=F_{1}:(200 M H z x 3), y 2=F_{2}(200 M H z x 2)$, $y 3=F_{3}:\left(4^{\circ} \mathrm{C}\right), y 4=F_{4}:(-18 \times 3), y 5=F_{4}:(-18 \times 2), y 6=F_{4}:(-18 \times 1)$

stability of the cross-linking component of biosensor receptor layers.

The same kind of analysis was performed for all measured external factors: F1: $200 \mathrm{MHz} \times 1, \mathrm{~F} 1: 200$ $\mathrm{MHz} \times 2, \mathrm{~F} 1: 200 \mathrm{MHz} \times 3, \mathrm{~F} 2: 1 \mathrm{NAA}, \mathrm{F} 2: 1 \mathrm{NAA} 4^{\circ} \mathrm{C}$, F2: $3 \mathrm{NAA}, \mathrm{F} 2$ : $3 \mathrm{NAA} 4^{\circ} \mathrm{C}, \mathrm{F} 3: 4^{\circ} \mathrm{C}, \mathrm{F} 3$ : microwave and $4^{\circ} \mathrm{C}, \mathrm{F} 4:-18^{\circ} \mathrm{C} \times 1, \mathrm{~F} 4:-18^{\circ} \mathrm{C} \times 2, \mathrm{~F} 4:-18^{\circ} \mathrm{C} \times 3, \mathrm{~F} 5: \mathrm{mi}-$ crowave $\times 2$, F5: microwavex3, F5: microwave $10 \mathrm{~s}, \mathrm{~F} 5$ : microwave $15 \mathrm{~s}$.

The obtained results of this compilation are shown in Fig. 3.

As it is seen (Fig. 3), two types of changes can be distinguished: changes where the "a" parameter is positive and changes for which " $a$ " is negative.

Factors which obtain positive value are interpreted as factors improving stability whereas the factors which obtain negative value are regarded as factors that reduce the stability of the cross-linking component of biosensor receptor layers:

Positive values have been noticed for F1: (200 $\mathrm{MHz} \times 1)$, F1: (200 $\left.\mathrm{MHz}_{z} \times 2\right)$, F13: (200 MHz×3), F2: (1NAA), F2: (1NAA $\left.4^{\circ} \mathrm{C}\right), \mathrm{F} 2:(3 \mathrm{NAA}), \mathrm{F} 2:$ (3NAA $\left.4^{\circ} \mathrm{C}\right), \mathrm{F} 3$ : $\left(4^{\circ} \mathrm{C}\right)$. Among them, the greatest stability has been achieved for $\mathrm{F} 2$ : $3 \mathrm{NAA} 4^{\circ} \mathrm{C}$ whereas negative values have been obtain for: $\mathrm{F} 3$ : (microwave and $4^{\circ} \mathrm{C}$ ), F4: $\left(-18^{\circ} \mathrm{C} \times 1\right), \mathrm{F} 4:\left(-18^{\circ} \mathrm{C} \times 2\right), \mathrm{F} 4:\left(-18^{\circ} \mathrm{C} \times 3\right)$, also for microwaves radiation: F5: (microwave $\times 2)$, F5: (microwave $\times 3$ ), F5: (microwave $10 \mathrm{~s}$ ), F5: (microwave $15 \mathrm{~s}$ ).

Based on this analysis it could be said that adding NAA to cross-linking component (BSA) improves its stability the most. NAA is known as a marker of neuronal injury in neurodegenerative disease (Schuff et al., 2006; Tai \& Coyle, 1995) For higher concentrations $(3 \mathrm{mg} / \mathrm{ml})$ of the added agent, stability was better than for lower concentrations (1 $\mathrm{mg} / \mathrm{ml} \mathrm{NAA})$. Additionally decreasing the temperature $\left(4^{\circ} \mathrm{C}\right)$ compounded the effect.

The performed studies also show a greater destabilizing effect of a significantly reduced temperature $\left(-18^{\circ} \mathrm{C}\right)$ than for the microwave radiation.

The presented diagram illustrates factors and its influence on the stability of the biosensor layer cross-linking component.

The destabilization changes in the receptor layer crosslinking component reflect an increase in the amount of helix conformation and a decrease in a beta-sheet structure which leads to loosing of the protein skeleton. It

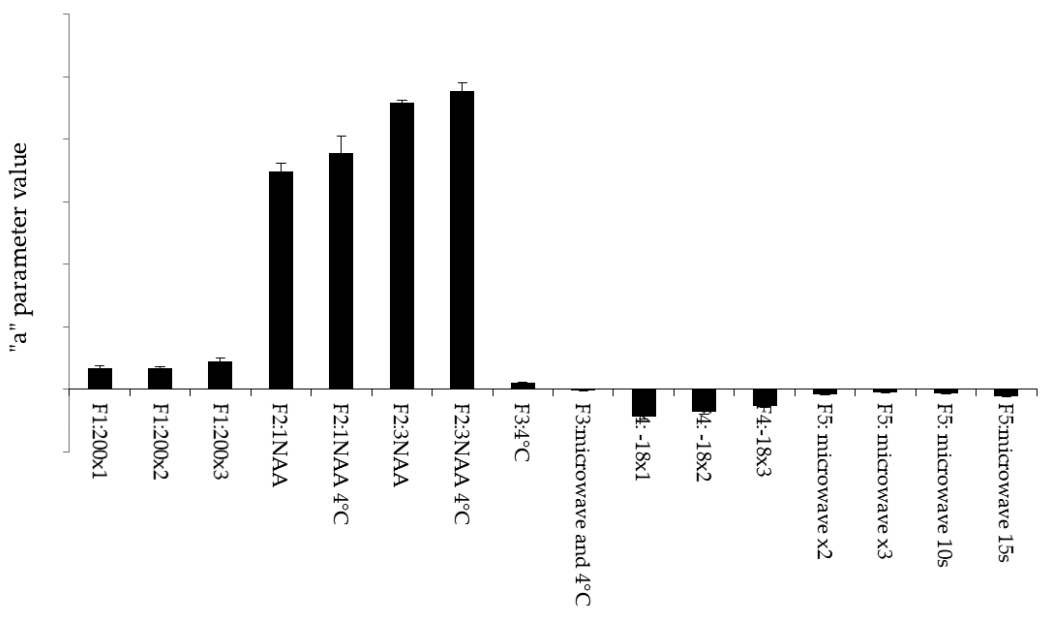

Figure 3. The "a" parameter value interpreted as a factor of improving or reducing the biosensor receptor layer stability 
also indicates that fragmentation and aggregation of the studied protein might occur with time. The protein fragmentation in an aqueous solution is affected by the local conformation of a particular amino-acid. Over time, the denaturation of proteins occurs. During this process, the tertiary structure of the protein is disrupted, resulting in loss of biological activity of the protein. Depending on external factors, the tested component of the biosensor matrix can be crushed in whole or only in part (Takeda et al., 1989) have discovered that secondary structural changes occur only after the reduction of disulfide bonds. Then, the helix content drops from $66 \%$ to $25 \%$, the structure content increases from $3 \%$ to $19 \%$. The receptor layer cross-linking component form may change over time and under the influence of external factors, such as $\mathrm{pH}$ and temperature. Further conformational changes were labelled as follows: $\mathrm{E}$ - expanded, F fast-highly changed state, $\mathrm{N}$ - normal, $55 \% \quad \alpha$-helix structure, B - basic and A - aged unfolded state. The N-F conformational transition is characterized by a sudden opening of the molecule. The process is very rapid and it means $100 \mathrm{~ms}$ and concerns the spreading of the third domain. The F form is characterized by a much lower solubility and decreased helix structure. The $\mathrm{E}$ form is a form of stretched protein, which decomposes into a helix I domain that is joined to the helix II domain. Another known conformation is the B conformation from which the next isomerization progresses to the ageing A forms (Michnik et al., 2005; Holiang et al., 2013). The stabilizing effect relates to the slowing down of changes taking place over time.

\section{CONCLUSIONS}

This paper presents a meta-analysis of the influence of the external conditions on the biosensor receptor layer component stability. The performed meta-analysis allowed to increase the precision and accuracy of the results by combining and co-analysing data. An approach of numerical interpretation of the qualitative stability changes has been offered. The conducted meta-analysis showed that the tested factors influence the stability of BSA in different ways. Factors improving the stability of the cross-linking component of biosensor receptor layers include radio frequency range $(200 \mathrm{MHz})$ and temperature of $4^{\circ} \mathrm{C}$. Higher stability was obtained after adding $\mathrm{NAA}$ and at $4^{\circ} \mathrm{C}$.

On the other hand, factors that reduce the stability of the cross-linking component of biosensor receptor layers include microwave radiation and reduction of temperatures to $-18^{\circ} \mathrm{C}$. It is also worth mentioning that differences between the sample exposed to a given factor and the control sample were higher over time.

The conducted meta-analysis shows the magnitude of differences in stability caused by chosen external factors.

The results obtained in the manuscript can be used in the design of biosensors. They help to determine the conditions for storage of that type of devices to prolong their stability.

\section{REFERENCES}

Grabowska J, Małecka J, Jarocka U, Radecki J, Radecka H (2014) Electrochemical biosensors for detection of avian influenza virus - current status and future trend. Acta Biochim Pol 61: 471-478. https:// doi.org/10.18388/abp.2014_1866

Hongliang X, Nannan Y, Haoran X, Tiansh W, Guiying, L, Zhrngqiang L (2013) Characterization of the interaction between eupatorin and bovine serum albumin by spectroscopic and molecu- lar modeling methods. Int J Mol Sci 14: 14185-14203. https://doi. org/10.3390/ijms140714185

Klos-Witkowska A (2017) The influence of microwave radiation dosed in fractional doses and single doses on the cross-linking component of biosensor matrices. Interdisciplinary project as a project of the 21 st century. Rysiński J ed, pp 147-154. Scientific Publishing House of the University of Bielsko-Biała.

Klos-Witkowska A (2018) Influence of fractional electromagnetic radiation doses on biosensor matrix component stability. Acta Phys Pol A 133: 101-104. https://doi.org/10.12693/APhysPolA.133.101

Klos-Witkowska A (2017) Testing stability of bovine serum albumin as a component of receptor layers in biosensors. Engineer of the 21st century. Rysiński J ed, pp 657-666. Scientific Publishing House of the University of Bielsko-Biała.

Klos-Witkowska A, Akhmetov B, Zhumangalieva N, Karpinskyi V, Gancarczyk, T (2016) Bovine Serum Albumin stability in the context of biosensors ICCAS 2016: 16th International Conference on Control, Automation and Systems. 2016; Wonpil Y, Partk S, Gomes L eds, pp 976-980

Klos-Witkowska A, Martsenyuk V (2020) Study of improvement of biosensor matrix stability. Engineer of the XXI Century. Zawiślak S, Rysińki J eds, 86941657. Springer. https://doi.org/10.1007/978-3030-13321-4_13

Klos-Witkowska A, Martsenyuk V, Rajba, S, Szklarczyk R, Więcław Ł (2018) Study of biosensor receptor layer component stability under the influence of variable environment acidity. 18th International Multidisciplinary Scientific Geo Conference. SGEM 637-644. https://doi. org/10.5593/sgem2018/6.2

Kucherenko IS, Topolnikova YaV, Soldatkin OO (2019) Advances in the biosensors for lactate and pyruvate detection for medical applications: A review. Trends Anal Chem 110: 160-172

Lin CH, Lee M, Lee W (2016) Bovine serum albumin detection and quantitation based on capacitance measurements of liquid crystals. Appl Phys Lett 109: 093703. https://doi.org/10.1063/1.4962169

Martsenyuk V, Warwas K, Augustynek K, Klos-Witkowska A, Karpinsky V, Klymuk N, Mayhruk Z (2016) On mutlivariate method of qualitative analysis of Hodgkin-Huxley model with decision tree induction. ICCAS 2016, 7832365: 489-494. https://doi.org/10.1109/ ICCAS.2016.7832365

Michnik A, Michalik K, Drzazga Z (2005) Stability of bovine serum albumin at diffent pH. J Therm Anal Calorim 80: 399-406. https:// doi.org/10.1007/s10973-005-0667-9

Mosinska L, Fabisiak K, Paprocki K, Kowalska M, Popielarski P, Szybowicz M, Stasiak A (2013) Diamond as a transducer material for the production of biosensors. Przemysl Chemiczny 92: 919-923

Neuhoff S, Artursson P, Zamora I, Ungell AL (2006) Impact of extracellular protein binding on passive and active drug transport across Caco-2 cells. Pharm Res 23: 350-359. https://doi.org/10.1007/ s11095-005-9304-3

Panjan P, Virtanen V, Sesay A (2017) Determination of stability characteristics for electrochemical biosensors via thermally accelerated ageing. Talanta 170: 331-336. https://doi.org/10.1016/j.talanta.2017.04.011

Sarika C, Rekha K, Narasimha Murthy B (2015) Studies on enhancing operational stability of a reusable laccase-based biosensor probe for detection of ortho-substituted phenolic derivatives. 3 Biotech 5: 911-924. https://doi.org/10.1007/s13205-015-0292-7

Schuff N, Meyerhoff DJ, Mueller S, Chao L, Sacrey DS, Laxer K, Weiner MW (2006) N-ACETYLASPARTATE as a marker of neuronal injury in neurodegenerative disease. Adv Exp Med Biol 576: 241-363. https://doi.org/10.1007/0-387-30172-0_17

Sirisha VL, Jain A, Jain A (2016) Enzyme immobilization an overview on methods, support material, and applications of immobilized enzymes. Adv Food Nutri Res 79: 179-211. https://doi.org/10.1016/ bs.afnr.2016.07.004

Sonawane A, Manickam P, Bhansali S (2017) Stability of enzymatic biosensors for wearable applications. IEEE Rev Biomed Eng 10: 174 186. https://doi.org/10.1109/RBME.2017.2706661

Tai G, Coyle J (1995) N-Acetylasparate in neuropsychiatric disorders. Prog Neurobiol 46: 531-540. https://doi.org/10.1016/03010082(95)00014-m

Takeda K, Wada A, Yamamoto K, Moriyama Y, Aoki (1989) Conformational change of bovine serum albumin by heat treatment. J Protein Chem 8: 653-659

Torres B, Seyeux A, Zanna S, Tribollet B, Marcus P, Frateur I (2013) Influence of BSA adsorption on the oxide layers developed on $70 \mathrm{Cu}-30 \mathrm{Ni}$ alloy in static artificial seawater. Mat'eriaux Techniq 101. https://doi.org/10.1051/mattech/2013059

Zhou F, Li G, Huang J (2019) Effect of Chitosan/BSA addition on the physical stability of sunflower oil emulsions. J Food Quality 2019: 6264270. https://doi.org/10.1155/2019/6264270

Żyracka E, Zadrag R, Kozioł S, Krzepiłko A, Bartosz G, Biliński T (2005) Yeast as a biosensor for antioxidants: simple growth tests employing a Saccharomyces cerevisiae mutant defective in superoxide dismutase. Acta Biochim Pol 52: 679-684 